\title{
A regenerative protocol and SEM study for in vitro propagation of Anthurium crossed lines via indirect somatic embryogenesis
}

\author{
G P Bhavana ${ }^{1}$, Kumudini Belur Satyan ${ }^{2}$ and C. Aswath ${ }^{3}$ \\ ${ }^{1,2}$ Centre for Post-Graduation Studies(CPGS), Jain University, Bengaluru, Karnataka, India \\ ${ }^{3}$ Division of Floriculture and Medicinal Crops, ICAR-Indian Institute of Horticultural Research, Bengaluru, \\ Karnataka, India
}

\begin{abstract}
A reproducible protocol for indirect somatic embryogenesis was established in the crosses of Anthurium. Two new lines namely - A1P and A2W were formed from the crosses of Anthurium ornatum and A. andraeanum. Leaf explants were selected based on coloured spathe having fragrances spadix (pink - A1P and white - A2W). Half-strength modified MS (lowering ammonium nitrate to $250 \mathrm{mg} / \mathrm{l}$ and for the first time - 0.1\% EDTA Ferric Sodium) medium supplemented with 2, 4-D (1.4 $\mu \mathrm{M})$ and 6-BAP $(4.4 \mu \mathrm{M})$ was found to induce high percentage $(82.6 \pm 0.57)$ of callus after 30 days in dark conditions (A2W). Later, MS basal medium having 6-BAP $(0.2-4.4 \mu \mathrm{M})$ was found to initiate shoot proliferation from the calluses of both the lines. The highest number of adventitious shoots were obtained in A2W(29.1 \pm 0.88$)$ compared to A1P $(26.8 \pm 0.33)$, at $1.3 \mu \mathrm{M} 6$-BAP after 6 weeks in 16/8 h light and dark cycle under a photoperiod of $50 \mu \mathrm{mol} / \mathrm{m} 2 / \mathrm{s}$. Separate rooting media was not required, and the best rooting occurred with $0.4 \mu \mathrm{M}$ and 1.3 $\mathrm{MM} 6$-BAP shooting media. The results showed that A2W line had different responses compared to A1P line, both for callus induction as well as number of shoots-per-explants. Shoots for both the lines increased in the multiplication stages and this increase in the number of shoots-per-explants was found significant $(p<0.01)$. The scanning electron microscopic (SEM) study also confirmed the stages of somatic embryogenesis from the leaf explants.
\end{abstract}

KEY WORDS: ANTHURIUM, 2, 4-D, 6-BAP, CALLUS, SEM, SOMATIC EMBRYOS(SE’S), ACCLIMATIZATION

\author{
ARTICLE INFORMATION: \\ *Corresponding Author: bhavana14590@gmail.com \\ Received $10^{\text {th }}$ Jan, 2018 \\ Accepted after revision $19^{\text {th }}$ March, 2018 \\ BBRC Print ISSN: 0974-6455 \\ Online ISSN: 2321-4007 CODEN: USA BBRCBA \\ Thomson Reuters ISI ESC / Clarivate Analytics USA and \\ Crossref Indexed Journal \\ NAAS Journal Score 2017: 4.38 SJIF 2017: 4.196 \\ - A Society of Science and Nature Publication, Bhopal India \\ 2018. All rights reserved. \\ Online Contents Available at: http//www.bbrc.in/ \\ DOI: $10.21786 / \mathrm{bbrc} / 11.1 / 5$
}




\section{INTRODUCTION}

Anthurium andraeanum Linden, the herbaceous, evergreen and perennial flower, belonging to the family Araceae, is popular and one of the most important cut flowers produced in the tropical and sub-tropical countries. Numerous species of these economically important genera are grown as potted cultivars and landscape plants.Species and hybrids within this monocotyledonous genus Anthurium, are highly prized as ornamentals for their beautiful showy flowers and exotic foliage, (Adelheid et al., 1992). In the global market, the Anthurium is valued only next to Orchids which rank first among the tropical cut flowers and the world import market size for Anthurium is estimated to exceed US\$ 20 million annually (Dufourand Guerin 2003; Chen et al., 2003; Atak and Celik 2009).

Traditionally, Anthuriumis propagated through seeds and offshoots or nodal cuttings. However these traditional methods have posed challenges for large-scale production as seeds are highly heterozygous. Also, the traditional methods of propagation involve a high endto-end timeline of around 3 years. On the other hand, plant tissue culture techniques have proved a better alternative for large-scale production of ornamental plants (Rout et al., 2006, Thokchom and Maitra, 2017 and Thaneshwari and Aswath, 2018).

Micropropagtion in particular, using bulking up via callus stage, followed by adventitious bud formation, has been proposed as an interesting possibility for commercial viability (Pierik et al., 1974). As an alternative, most commercial tissue culture laboratories now favour axillary bud proliferation techniques for Anthurium. Nevertheless, neither of these techniques are free from the associated de-merits. While the micropropagtion technique results in formation of off-types (Geier, 1988), axillary bud proliferation technique has serious problems with weaning of material, not withstanding a low propagation rate (Hamidahn et al., 1997, Thokchom and Maitra, 2017).

Because of all the afore mentioned problems with conventional method - in vitro and in vivo propagation techniques, the possibility of producing micro shoots via somatic embryogenesis was considered the best for mass propagation because, 1) the high multiplication rate, 2) the ease of use of liquid medium, 3) the handling of enormous numbers of embryos at one time, 4) and the possible use of bioreactors (Merkle et al., 1990). Though a good number of conventional protocols have been developed for various explants (Pierik et al.,1974; Kunisaki 1980; Kuehnle and Sugii 1991; Matsumoto and Kuehnle 1997; Martin et al.,2003; Viégas et al., 2007; Beyramizade et al., 2008), somatic embryogenesis has been less commonly reported in A. andraeanum (Teixeira da Silva et al., 2015). Kuehnle et al., (1992) firstly reported somatic embryogenesis from leaf blade derived embryogenic calli, and the histological evidence for bipolar structure of somatic embryos (SEs) and their origin was put forward by Matsumoto et al., (1996) (Bhattacharya et al., 2016, Thaneshwari and Aswath, 2018).

An embryogenic-like callus of $A$. andraeanum, cultured on medium containing 2,4-D and BA was described by Kuehnle and Sugii (1991). Plants were readily obtained from that callus but regeneration from somatic embryos was not demonstrated. Later, somatic embryos and plant regeneration was reported using an induction medium containing 2,4-D and kinetin (Kuehnle et al., 1992). Embryo-like structures were observed by Geier (1982), using spadix explants of A.scherzerianum, but plants were not recovered. Recently, somatic embryogenesis was reported using nodal segments from in vitro established plantlets that were cultured in Pierik medium supplemented with $10 \mu \mathrm{M}$ NAA (Marcos et al., 2014). In this study, we are reporting a novel in vitro protocol for plant regeneration of the lines of crosses between $A$. ornatumand $A$. andraeanum,through indirect somatic embryogenesis from leaf explants of field grown plants, and their acclimatization to field conditions. The stages of embryo developmental process have been elaborated through morphological analysis. Finally somatic embryos were confirmed through scanning electron microscopic (SEM) studies.

\section{MATERIAL AND METHODS}

Plant materials and explant preparation: The study was conducted at Centre for Post-Graduation Studies, Jain University, Karnataka, India. Lines were obtained by crossing $A$. ornatum and $A$. andraeanum and are selected based on the combination of colour and fragrance of the flowers. For culturing callus, young $e x$ vitro leaf explants ( $2-4$ days old) were collected from these lines. For surface sterilization, the folded young leaves were thoroughly washed with running tap water for $5 \mathrm{~min}$. All the further steps of surface sterilization were followed inside the laminar air flow chamber. Initially explants were swabbed with 70\% ethanol,and later cut into $5 \mathrm{~cm}$ squares. Cut pieces were then treated with sterile double-distilled (DD) water for $5 \mathrm{~min}$, soaked in $1 \%$ bavistin for $15 \mathrm{~min}, 70 \%(\mathrm{~V} / \mathrm{V})$ ethanol for $30 \mathrm{sec}$, antibiotic gentamycin for $30 \mathrm{~min}$, and finally followed by mixture of 1\% (w/v) sodium hypochlorite [5.0\% (w/v) available chlorine, (Nice - Kochi) solution] and Twin 20 (Nice - Kochi) (1-2 drops) for $12 \mathrm{~min}$. Each chemical treatment was followed by washing with sterilized DD water for five times. Before inoculation, leaves were cut into $1 \mathrm{~cm}$ squares, pricked few times with a sterilized scalpel and placed on culture media with the adaxial 
surface down. The cultures after inoculation were incubated under cool and dark conditions at $25 \pm 2.0^{\circ} \mathrm{C}$ and 70\% relative humidity (RH) (Bhattacharya et al., 2016).

Culture media for induction of SE's: The basal MS medium (Murashige and Skoog's, 1962) supplementedwith 3\% (w/v) sucrose and 0.8\% (w/v) agar (Bacteriological grade, Hi-media) was used for one set of treatment. Half-strength Modified MS (MMS), first time for callus induction, was used for the other set of treatment. This Half-strength MMS medium was prepared, by modifying the basal MS medium for lower concentrations of ammonium nitrate (250mg/l) (Atak and Celik, 2009; Nhut et al., 2006) and for the first time reducing iron content to 0.1\% - EDTA Ferric Sodium (Duchefa biochemie). Both the sets were supplementing with different combinations of 2,4-Dichlorophenoxyacetic acid (2,4-D, Hi-media) concentrations ranging from $0-2.3 \mu \mathrm{M}$ and 6-Benzyladenine (6-BAP, Hi-media) concentrations of 2.2 and $4.4 \mu \mathrm{M}$. The $\mathrm{pH}$ was then adjusted to $5.8-6.0$ with $1 \mathrm{~N} \mathrm{NaOH}$ before autoclaving at $1.1 \mathrm{~kg} / \mathrm{cm}^{2}$ pressure $\left(121^{\circ} \mathrm{C}\right)$ for $15 \mathrm{~min}$.

Culture media and condition for shoot and root induction: For the shoot and root induction, only Basal MS medium was supplemented with different concentrationsof 6-6-BAP $(0-2.2 \mu \mathrm{M}), 3 \%(\mathrm{w} / \mathrm{v})$ sucrose and $0.8 \%$ $(\mathrm{w} / \mathrm{v})$ agar was used. The $\mathrm{pH}$ was adjusted to same level of 5.8 - 6.0 with $1 \mathrm{~N} \mathrm{NaOH}$ before autoclaving at 1.1 $\mathrm{kg} / \mathrm{cm}^{2}$ pressure $\left(121^{\circ} \mathrm{C}\right)$ for $15 \mathrm{~min}$. The incubation of cultures after inoculation in controlled condition was under cool, white fluorescent lights $(16 \mathrm{~h}$ photoperiod; $55 \mu \mathrm{mol} \mathrm{m} \mathrm{s}^{-2}$, Philips, India) at $25 \pm 2.0^{\circ} \mathrm{C}$ and $70 \%$ relative humidity (RH).

Acclimatization: A well-developed 50 plantlets (25 plantlets from each line of both the media) were selected and planted for primary hardening. Prior to this plantlets were first washed with tap water to remove traces of media followed by soaking in bavistin $(0.2 \%)$ solution for 2 minutes and then transferred to trays containing jiffy plugs in the plant growth chambers. After 30 days of primary hardening under artificial light, the plantlets were transferred to pots containing cocopeat in the humidity chamber of poly house. To maintain humidity, the seedlings were covered with 100 gauge thick polythene covers. After 30 days of secondary hardening, seedlings were transferred to individual pots with potting mixture containing soil, dung manure, cocopeat $1: 1: 1$. The data was analysed for survival rate.

SEM studies: Hitachi Table top Scanning Electron Microscope (TM3030 plus) with Variable Pressure (VPSEM) detectors was used. Both Scattered Electron (SE) and Back Scattered Electron 9BSE) detectors were used in 80:20 mix, at $15 \mathrm{KVA}$. The samples were imaged without any dehydration, and were not coated. Magnification was in the range of $80-1800 X$.

Statistical analysis: The results are presented as mean values \pm standard errors. All experiments were repeated three times.The data on callus induction rate and number of shoot-per-explant were subjected to analysis of variance (ANOVA) with the means separation $(p<0.01)$ by Web Based Agricultural Statistics Software Package (WASP.2) - Central coastal Agricultural Research Institute Goa available at www.icargoa.res.in - (Shawaf et al., 2012).

\section{RESULTS AND DISCUSSION}

The results from the present study demonstrated that indirect somatic embryogenesis from leaf explants of crosses between two monocotyledonous plants $A$. ornatum and $A$. andraeanum. Lines produced from the cross between the two species gave coloured and fragrant flowers, the combination which is not available in its natural form/habitat. Owing to the monocotyledonous nature of the plants, the embryogenic potentiality is generally restricted to cells of meristems or embryogenic origin such as shoot apices, lateral buds, immature embryos, and seeds (Fehér, 2005). In our study, cut pieces of young leaves were used as explants procured from field grown plants. The leaf tissue has been widely used for organogenesis (Kuehnle and Sugii1991; Kumari et al. 2011) and indirect somatic embryogenesis (Kuehnle et al. 1992; Beyramizade et al. 2008) of A. andraeanum. Medium composition and PGR concentrations have a key role in the formation and differentiation of calli (Thaneshwari and Aswath, 2018).

Geier in 1986 clearly mentioned that lowering of $\mathrm{NH}_{4} \mathrm{NO}_{3}$ had a significant effect on callus and shoot formation especially from leaf tissue. A low level of $\mathrm{NH}_{4} \mathrm{NO}_{3}$ $(200 \mathrm{mg} / \mathrm{l})$ proved beneficial for the induction and regeneration in all genotypes of Anthurium. Faris et al., (2012) and Atak and Celik (2009) reported that, (250mg/l) $\mathrm{NH}_{4} \mathrm{NO}_{3}$ helps for shoot regeneration. Iron (NaFeEDTA) is one of the major micro elements in MS media, helps for the growth and development of plants. Lower concentration of $\mathrm{Na}$ Fe EDTA (30-25 mg/l) helps in induction and maturation of both zygotic and somatic embryos (Matsumoto et al., 1998 and Beyramizade et al., 2008). In the present study, for the first time half strength MMS having (250mg/l) $\mathrm{NH}_{4} \mathrm{NO}_{3}$ and (0.1\%) EDTA Ferric Sodium was used for callus induction and maturation.

Generally, auxin is used for the conversion of somatic cells to embryogenic cells. Pinheiro et al. (2014) demonstrated that in A. andraeanum, Pierik basal medium (Pierik et al. 1974) supplemented either with NAA, or Picloram or 2, 4-D produced highest number of SEs from 


\begin{tabular}{|c|c|c|c|c|c|c|c|}
\hline \multicolumn{4}{|c|}{ Full MS } & \multicolumn{4}{|c|}{ Half MMS } \\
\hline \multirow[t]{2}{*}{ 6-BAP $(\mu \mathrm{M})$} & \multirow[t]{2}{*}{$2,4-\mathrm{D}(\mu \mathrm{M})$} & \multicolumn{2}{|c|}{$\%$ of callus } & \multirow[t]{2}{*}{ 6-BAP $(\mu \mathrm{M})$} & \multirow[t]{2}{*}{$2,4-\mathrm{D}(\mu \mathrm{M})$} & \multicolumn{2}{|c|}{$\%$ of callus } \\
\hline & & (A1P) & $(\mathrm{A} 2 \mathrm{~W})$ & & & (A1P) & $(\mathrm{A} 2 \mathrm{~W})$ \\
\hline 0.0 & 0.0 & $1.013 \pm 0 \mathrm{~b}$ & $1.013 \pm 0 \mathrm{~b}$ & 0.0 & 0.0 & $1.013 \pm 0 \mathrm{~b}$ & $1.013 \pm 0 \mathrm{~b}$ \\
\hline 2.2 & 0.5 & $1.013 \pm 0 b$ & $1.013 \pm 0 \mathrm{~b}$ & 2.2 & 0.5 & $1.013 \pm 0 \mathrm{~b}$ & $1.013 \pm 0 \mathrm{~b}$ \\
\hline 2.2 & 0.9 & $1.013 \pm 0 \mathrm{~b}$ & $1.013 \pm 0 \mathrm{~b}$ & 2.2 & 0.9 & $1.013 \pm 0 \mathrm{~b}$ & $1.013 \pm 0 \mathrm{~b}$ \\
\hline 2.2 & 1.4 & $1.013 \pm 0 \mathrm{~b}$ & $1.013 \pm 0 \mathrm{~b}$ & 2.2 & 1.4 & $1.013 \pm 0 \mathrm{~b}$ & $1.013 \pm 0 \mathrm{~b}$ \\
\hline 2.2 & 1.8 & $1.013 \pm 0 \mathrm{~b}$ & $1.013 \pm 0 \mathrm{~b}$ & 2.2 & 1.8 & $1.013 \pm 0 \mathrm{~b}$ & $1.013 \pm 0 \mathrm{~b}$ \\
\hline 2.2 & 2.3 & $1.013 \pm 0 \mathrm{~b}$ & $1.013 \pm 0 \mathrm{~b}$ & 2.2 & 2.3 & $1.013 \pm 0 \mathrm{~b}$ & $1.013 \pm 0 \mathrm{~b}$ \\
\hline 4.4 & 0.5 & $1.013 \pm 0 \mathrm{~b}$ & $1.013 \pm 0 \mathrm{~b}$ & 4.4 & 0.5 & $1.013 \pm 0 \mathrm{~b}$ & $1.013 \pm 0 \mathrm{~b}$ \\
\hline 4.4 & 0.9 & $40.16 \pm 0.35 a$ & $42.8 \pm 0.52 \mathrm{a}$ & 4.4 & 0.9 & $1.013 \pm 0 \mathrm{~b}$ & $1.013 \pm 0 \mathrm{~b}$ \\
\hline 4.4 & 1.4 & $1.013 \pm 0 \mathrm{~b}$ & $1.013 \pm 0 \mathrm{~b}$ & 4.4 & 1.4 & $76.9 \pm 0.35 a$ & $82.59 \pm 0.56 \mathrm{a}$ \\
\hline 4.4 & 1.8 & $1.013 \pm 0 \mathrm{~b}$ & $1.013 \pm 0 \mathrm{~b}$ & 4.4 & 1.8 & $1.013 \pm 0 \mathrm{~b}$ & $1.013 \pm 0 \mathrm{~b}$ \\
\hline 4.4 & 2.3 & $1.013 \pm 0 b$ & $1.013 \pm 0 b$ & 4.4 & 2.3 & $1.013 \pm 0 \mathrm{~b}$ & $1.013 \pm 0 b$ \\
\hline
\end{tabular}

callus. Atak and Celik 2009 reported that, Half-strength MS basal salt with $0.6 \mathrm{mg} / 1$ 2,4-D, $1 \mathrm{mg} / \mathrm{l}$ BA were used for callus induction.Later, MS media containing (1.0 $\mathrm{mg} / \mathrm{l}) \mathrm{BA}$ and $(0.1 \mathrm{mg} / \mathrm{l})$ 2,4-D resulted in 2.08 shoots from the callus clumps was reported by Bakhsi-Khaniki et al., (2011) (Cardoso and Habermann, 2014). However, for the first it was observed that, indirect somatic embryogenesis using leaf explants of crossed Anthurium lines requires both 2 , 4-D $(1.4 \mu \mathrm{M})$ and 6-BAP $(4.4 \mu \mathrm{M})$ in Half strength modified MS medium.

Callus was initiated at the four corners of each leaf explant within 15 days of inoculation in the MS media containing 2, 4-D and 6-BAP. The leaf explants cultured on MS basal medium without growth hormone did not show any morphogenetic changes. Callus formation (over a period of 30 days) was observed in both the lines on leaf explants, with Half-strength MMS as well as FullMS media. However, only a particular concentrationof hormones formed callus - Half MMS containing $1.4 \mu \mathrm{M} 2,4,-$ Dand $4.4 \mu \mathrm{M}$ 6-BAP,and Full MS medium containing $0.9 \mu \mathrm{M} \mathrm{2,4,-D}$ and $4.4 \mu \mathrm{M}$ 6-BAP. In this study, it was clear that Half-strength modified MS medium, 6-BAP with 2,4-D was required for SE induction but the presence of only low concentrations of 2,4-D $(1.4 \mu \mathrm{M})$ for initiation of callus was adequate for maturation and germination of embryos.Callus induction percentage of explants at different concentrations of 2, 4-D (0-2.3 $\mu \mathrm{M})$ and 6-BAP $(2.2$ and $4.4 \mu \mathrm{M})$ for both Full MS and Half-strength MMS is given in Table 1. In our observations, irrespective of the lines, Half-MMS induced higher percentage of callus as well as matured embryos-per-explant compared to Full-MS media. With Half-MMS, white line showed better response than pink line. Callus initiation for $(82.6 \pm 0.57)$ in $\mathrm{A} 2 \mathrm{~W}$ compared to $(76.9 \pm 0.35) \mathrm{A} 1 \mathrm{P}$, and number of advanced stage of embryos-per explant of $(4.27 \pm 0.12)$ in A2W compared to $(3.13 \pm 0.088)$ A1P. Similar pattern was observed in Full-MS media as well where, white lines showing higher response compared to pink line for callus initiation $(42.8 \pm 0.52)$ in $\mathrm{A} 2 \mathrm{~W}$ compared to $(40.16 \pm 0.35) \mathrm{A} 1 \mathrm{P}$, and number of advanced stage of embryos-per-explant of $(2.16 \pm 0.88)$ in A2W as compared to $(1.23 \pm 0.14)$ A1P. The SEM studies also confirmed the indirect somatic embryogenesis stages which are formed during maturation (Fig. 2) and finally initiation of adventitious shoot development were also observed (Fig. 2f).

\begin{tabular}{|c|c|c|c|c|c|c|}
\hline Media & $\begin{array}{l}\text { 6-BAP } \\
(\mu \mathrm{M})\end{array}$ & $\begin{array}{l}2,4-\mathrm{D} \\
(\mu \mathrm{M})\end{array}$ & $\begin{array}{l}\text { \% of embryo forming } \\
\text { explants (A1P) }\end{array}$ & $\begin{array}{l}\text { \% of embryo forming } \\
\text { explants (A2W) }\end{array}$ & $\begin{array}{l}\text { No. Of SE's/ } \\
\text { explant (A1P) }\end{array}$ & $\begin{array}{l}\text { No. Of SE's/ } \\
\text { explant (A2W) }\end{array}$ \\
\hline Full MS & 4.4 & 0.9 & $27.305 \pm 2.1 \mathrm{~b}$ & $36.934 \pm 1.47 \mathrm{~b}$ & $1.233 \pm 0.15 b$ & $2.167 \pm 0.89 b$ \\
\hline $\begin{array}{l}\text { Half } \\
\text { MMS }\end{array}$ & 4.4 & 1.4 & $55.528 \pm 4.93 a$ & $66.955 \pm 3.1 \mathrm{a}$ & $3.133 \pm 0.09 a$ & $4.267 \pm 0.12 \mathrm{a}$ \\
\hline \multicolumn{7}{|c|}{$\begin{array}{l}\text { Values are mean } \pm \text { standard error of three replicated experiments each with } 6 \text { matured embryos generated in medium containing Full } \\
\text { MS }+0.9 \mu \mathrm{M} 2,4-\mathrm{D}+\mathrm{BA} 4.4 \mu \mathrm{M} \text {; Half strength MMS }+1.4 \mu \mathrm{M} 2,4-\mathrm{D}+\mathrm{BA} 4.4 \mu \mathrm{M} \text {. Means followed by the same letter are not significantly different at } \\
\mathrm{P}<0.01 \text {. Number of SE's was counted after } 30 \mathrm{~d} \text { of culture. }\end{array}$} \\
\hline
\end{tabular}




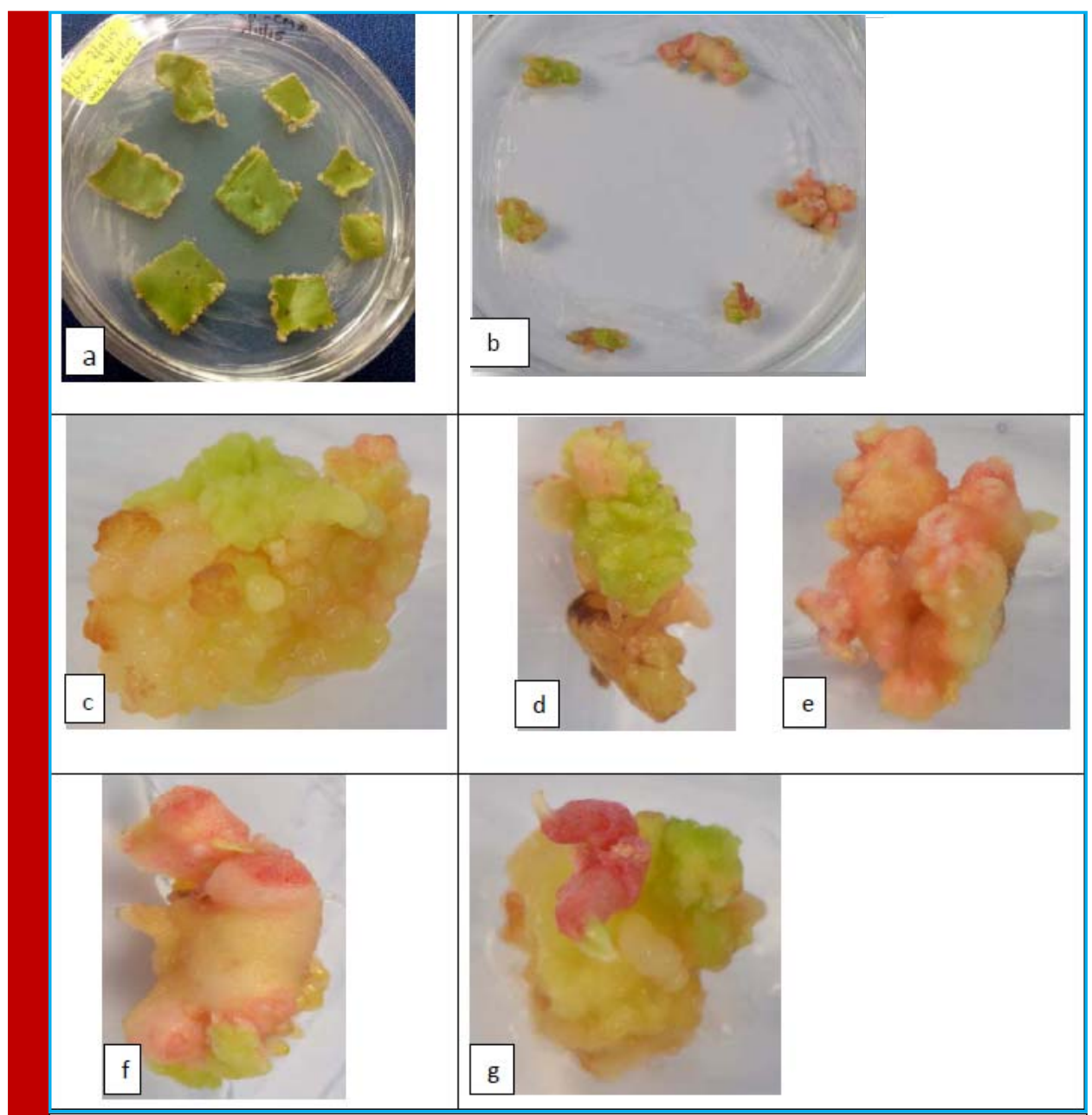

FIGURE 1. Somatic embryogenesis in leaf of Anthurium crossed lines (A1P and A2W). (a) Exvitro leaf segment cultured in Half MMS medium with $1.4 \mu \mathrm{M} 2,4,-\mathrm{D}$ and $4.4 \mu \mathrm{M}$ 6-BAP; all four edges of leaf shows callus formation, after 30 days of In vitro culture.

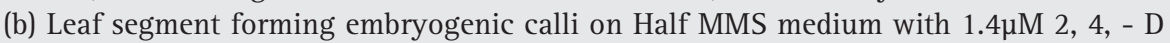
and 4.4 $\mu \mathrm{M}$ 6-BAP, after 30 days of culture In vitro. (c) (d) (e) and (f) stages of somatic embryos - globular, torpedo, heart and cotyledonary stages. (g) matured embryos showing the shoot initiation

\begin{tabular}{|c|c|c|}
\hline $\begin{array}{l}\text { Media - Full MS } \\
\text { 6-BAP }(\mu \mathrm{M})\end{array}$ & $\begin{array}{l}\text { No. of Germinated } \\
\text { embryos into plants (A1P) }\end{array}$ & $\begin{array}{l}\text { No. of Germinated } \\
\text { embryos into plants (A2W) }\end{array}$ \\
\hline 0.0 & $4.61 \pm 0.17 d$ & $5.18 \pm 0.17 c$ \\
\hline 0.4 & $9.39 \pm 0.08 b$ & $10.61 \pm 0.21 \mathrm{a}$ \\
\hline 0.9 & $7.33 \pm 0.33 c$ & $8.09 \pm 0.29 b$ \\
\hline 1.3 & $11.44 \pm 0.2 \mathrm{a}$ & $11.44 \pm 0.16 \mathrm{a}$ \\
\hline 1.8 & $6.62 \pm 0.08 c$ & $7.96 \pm 0.38 b$ \\
\hline 2.2 & $6.97 \pm 0.28 c$ & $7.29 \pm 0.44 b$ \\
\hline
\end{tabular}




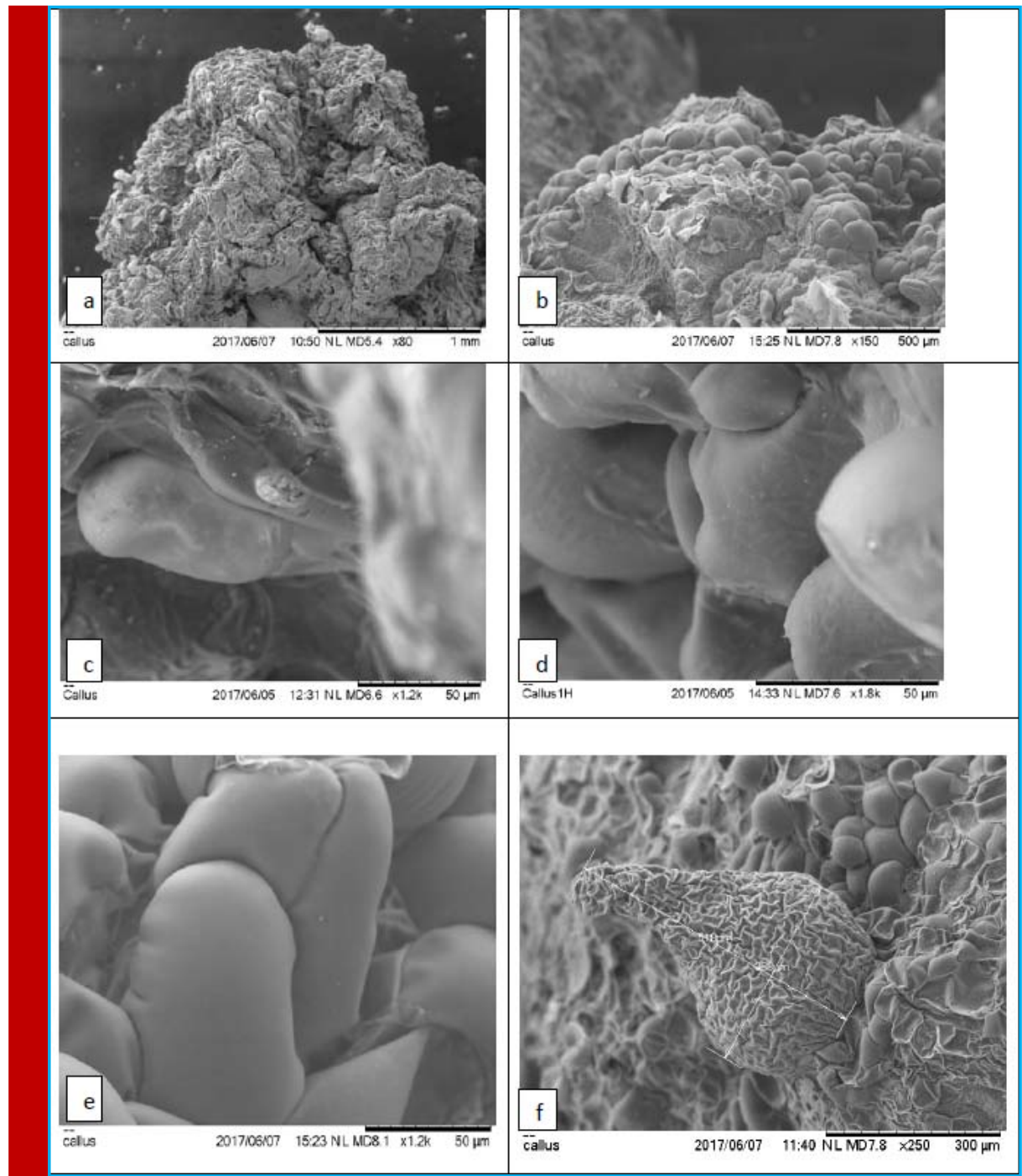

FIGURE 2. SEM analysis of indirect somatic embryogenesis from leaf explants of Anthurium lines.The value following $\mathrm{x}$ is the magnification ranges from $80-1800$ X. (a) Tightly packed cells of outer surface and large number of somatic cells with definite plane of divisions. (b) Globular protrusions. (c) (d) and (e) Torpedo, Heart and cotyledonary stages of somatic embryos. (f) Shoot tip emergence from the surface of matured embryos.

When the same media was used for second subculture of undifferentiated callus, Half-strength MMS showed higher percentage and number of SEs compared to Full MS medium (Fig. 1b). As shown in Table 2, Half-strength MMS at $67 \%$ for A2W $(4.26 \pm 0.120)$ and $55.5 \%$ for A1P $(3.13 \pm 0.088)$ vis-à-vis Full MS at $36.9 \%$ for A2W $(2.17 \pm 0.88)$ and $27.3 \%$ for A1P $(1.23 \pm 0.15)$. Stages of somatic embryos were morphologically identified (Fig. 1c, d,e, and f). The different concentrations of 6-BAP $(0-2.2 \mu \mathrm{M})$ had a noticeable effect on embryo germination. Matured somatic embryos showed highest number of germination $(11.43 \pm 0.067)$ in Full MS 6-BAP at $1.3 \mu \mathrm{M}$ for both the lines (Table 3). Hence our result suggested that less amount of 2,4 - D and 6-BA $4.44 \mu \mathrm{M}$ gives increased number of matured somatic embryos (Pinheiro et al., 2013, Yu Yi-xun et al., 2009).

Shoot induction using 6-BAP at $1 \mathrm{mg} \mathrm{L}^{-1}$ has been reported for this genus by Pierik (1976). Liendo and Mogollon (2009) obtained similar results for $A$. andreanum; in which 4.17 number of shoots were produced in a medium with $1 \mathrm{mg} \mathrm{L}^{-1}$ of 6-BAP. Later Paola et al., (2014) obtained in a $1 / 2$ MS (Half-salt content) medium with $1 \mathrm{mg} \mathrm{\textrm {L } ^ { - 1 }}$ of BAP, which attained 23.7 shoots / explant per month multiplication rate; In our study, we were able to achieve higher levels of shoot induction at $1.3 \mu \mathrm{M}$ 6-BAP $\left(0.3 \mathrm{mg} \mathrm{L}^{-1}\right)$. The highest 


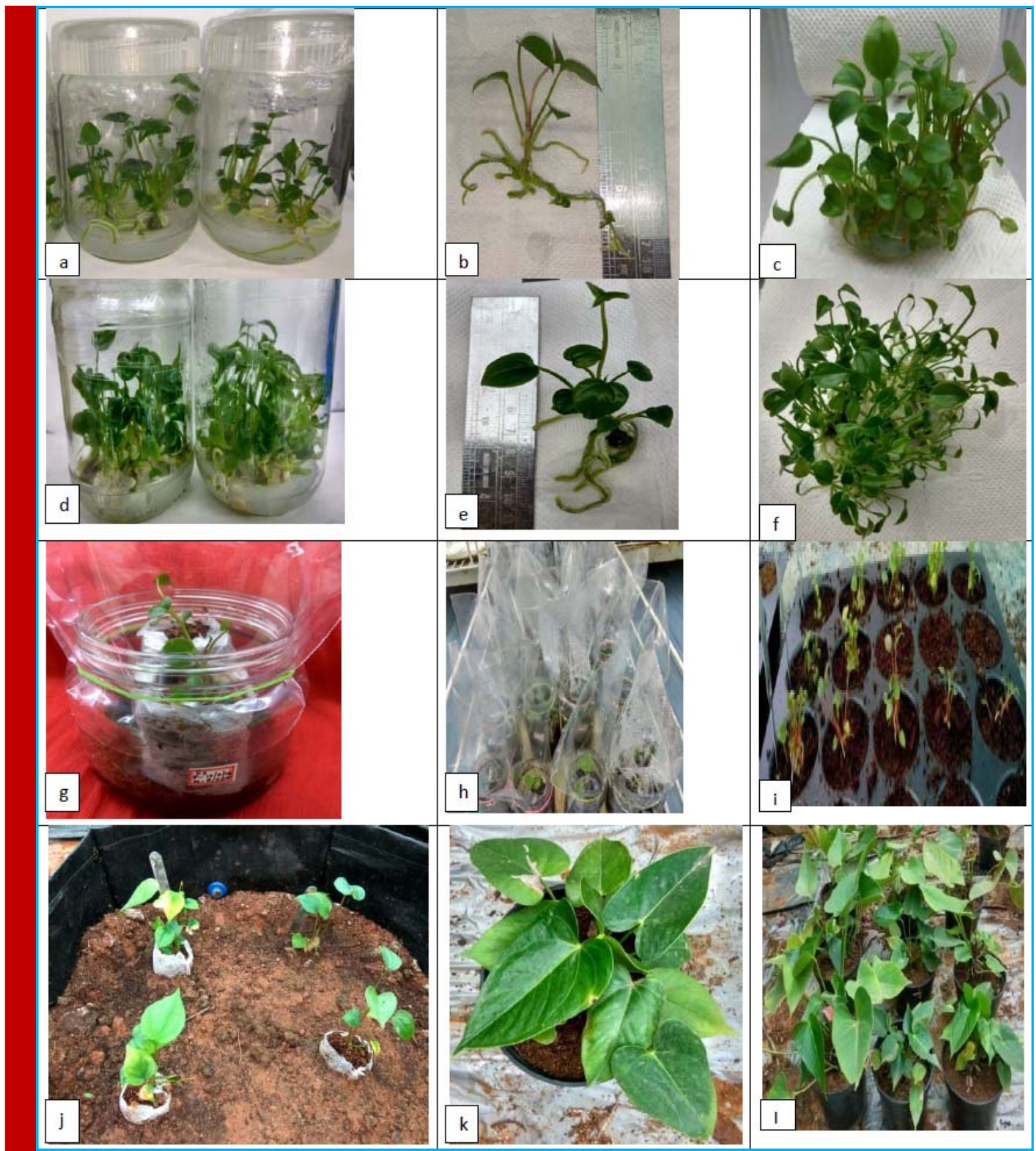

FIGURE 3. (a) And (d) A1P; A2W - Shoot multiplication occurring on the multiplication medium (1.3 $\mu \mathrm{M}$ 6-BAP). (b) and (e) individual plantlets shoot and root length of A1P; A2W (c) and (f) multiple shoots of A1P; A2W lines (g) and (h) Plants acclimatized under artificial light and room temperature at growth chamber primary hardening (i) Secondary hardening plants - autoclave cocopeat, humidity chamber of poly house. (j) Anthurium - grow bags (k) individual potted plant and (l) plant from culture 3 months after potting

number of shoots were observed in A2W $(29.1 \pm 0.89)$ compared to A1P $(26.8 \pm 0.33)$. Rooting for anthurium does not require any phytohormones; the occurrence of spontaneous roots has already been reported by other authors for this genus (Viegaset al., 2007; Liendo and Mogollon, 2009, Paola et al., 2014); therefore, one spe- cific medium for forming this organ is not necessary. Recently, Farsi et al. (2012) reported rooting without the addition of phytohormones for the micropropagation of $A$. Andreanum $c v$. Terra. Furthermore, different researchers have reported rooting in 84 to $100 \%$ of the shoots of different varieties of $A$. andreanum using 
Table 4. Effect of different concentrations of 6-BAP for shoot induction - (A1P)

\begin{tabular}{|l|l|l|l|l|}
\hline Media Full MS+ 6-BAP $(\mu \mathrm{M})$ & No. of shoots & Length of shoots & No. of roots & Length of roots \\
\hline 0.0 & $9.36 \pm 0.33 \mathrm{~d}$ & $9.26 \pm 0.21 \mathrm{e}$ & $9.36 \pm 0.33 \mathrm{~d}$ & $5.12 \pm 0.17 \mathrm{f}$ \\
\hline 0.4 & $24.34 \pm 0.57 \mathrm{~b}$ & $14.57 \pm 0.08 \mathrm{~b}$ & $13.34 \pm 0.33 \mathrm{~b}$ & $6.192 \pm 0.18 \mathrm{e}$ \\
\hline 0.9 & $16.77 \pm 3.84 \mathrm{c}$ & $10.51 \pm 0.08 \mathrm{~d}$ & $12.46 \pm 0.33 \mathrm{bc}$ & $8.65 \pm 0.15 \mathrm{c}$ \\
\hline 1.3 & $26.80 \pm 0.33 \mathrm{a}$ & $16.70 \pm 0.15 \mathrm{a}$ & $18.11 \pm 0.33 \mathrm{a}$ & $14.17 \pm 0.25 \mathrm{a}$ \\
\hline 1.8 & $17.78 \pm 0.33 \mathrm{c}$ & $13.96 \pm 0.33 \mathrm{~b}$ & $11.016 \pm 0.33 \mathrm{~cd}$ & $10.35 \pm 0.15 \mathrm{~b}$ \\
\hline 2.2 & $16.41 \pm 0.57 \mathrm{c}$ & $12.29 \pm 0.15 \mathrm{c}$ & $9.88 \pm 0.57 \mathrm{~d}$ & $6.95 \pm 0.033 \mathrm{~d}$ \\
\hline
\end{tabular}

Values are mean \pm standard error of three replicated experiments in the shoot induction medium containing 6-BAP(0- $2.2 \mu \mathrm{M})$. Means followed followed by the same letter are not significantly different at $\mathrm{P}<0.01$. Data were scored after $60 \mathrm{~d}$ of culture.

growth regulators (Martin et al., 2003; Bejoy et al., 2008; Islam et al., 2010; Paola et al., 2014).

The results are in accordance with, though separate rooting media was not used for root initiation, the highest level of rooting (A2W: $20.0 \pm 0.33$ and A1P: 18.1 \pm 0.33 ) was found in with $1.3 \mu \mathrm{M}$ 6-BAP in the shooting media itself. The root initiation was lower (A2W: $10.5 \pm 0.33$ and A1P: $9.4 \pm 0.33$ ) in the absence of 6-BAP. Root formation takes place in the 6-BAP media along with shooting (Fig 3a, b, c, d, e, and f). The different concentration of 6-BAP ensures difference in the number and length of shoots and roots. Full MS 6-BAP (1.3 $\mu \mathrm{M})$ showed highest number of shoots $(29.1 \pm 0.88)$ and roots $(19.96 \pm 0.33)$ in A2W (Table 5) than in A1P - shoots $(26.8 \pm 0.33)$ and roots $(16.7 \pm 0.15)$ (Table 4). Overall, the callus induction was significantly high in $\mathrm{A} 2 \mathrm{~W}$, the number of shoots-per-explants were more-or-less comparable across both the lines.

For transplantation of Anthurium plants, peat and sand mixture, (Geier, 1986) peat compost (Finnie and van Staden1986), burned-rice husk, raw rice husk and organic manure $(2: 2: 1 \mathrm{v} / \mathrm{v} / \mathrm{v})$ (Winarto and da Silva 2012), etc. were used. In the present work, for the first time, jiffy plugs were used for primary hardening. The embryo-generated plants from germination medium were directly harvested (Fig. 3a and 3d) and planted into jiffy plugs (Fig. $3 \mathrm{~g})$. The highest percentages (80\%) of the SE derived plantlets were successfully hardened in plant growth chambers (Fig. 3h) within 30 days. Based on the experiment by Sinta, Riyadi, \& Sumaryono (2011), the usage of plastic wrap as culture closures provides aeration for in vitro cultured oil palm. It helps to exchange the gas from inside to the outside of culture vessels to be more intense, which leads to the reduction in moisture. However, to compensate with the high evaporation, double layer medium was used for hardening (Saptari et al., 2017) so that plantlets were not completely dried. After 60days of secondary hardening in the cocopeat (Fig. 3i) at poly house, shows $78.3 \%$ of plants survived and were transferred to grow bags (Fig. 3j). Anthurium after 3 months in pots (Fig. 3k) results in flowering. Fig. 3l shows emergence of flower bud.The SEM study also confirmed the occurrence of somatic embryogenesis from epidermal layer of leaf tissue. The stages clearly indicated the embryo maturation leading to the formation of shoots (Fig. 2f) (Bhattacharya et al., 2016).

All stages in the somatic embryos were clearly identified in our studies which will leads to the conformation of somatic embryogenesis.Through the experiment, the objective was to find a suitable method of indirect somatic embryogenesis for the crossed lines. Different genotypes within the two lines were chosen; it was observed that there was a different response for callus induction and shoot formation among the lines. However, the present investigation demonstrated that the regeneration protocol shows good responses for both the Anthurium lines.

\begin{tabular}{|c|c|c|c|c|}
\hline Media Full MS $+6-\mathrm{BAP} \mu \mathrm{M}$ & No. of shoots & Length of shoots & No. of roots & Length of roots \\
\hline 0.0 & $8.94 \pm 0.29 \mathrm{f}$ & $11.30 \pm 0.29 \mathrm{~d}$ & $10.49 \pm 0.33 \mathrm{e}$ & $4.40 \pm 0.21 \mathrm{c}$ \\
\hline 0.4 & $22.95 \pm 0.2 b$ & $14.66 \pm 0.70 \mathrm{~b}$ & $16.07 \pm 0.33 \mathrm{~b}$ & $12.92 \pm 0.26 \mathrm{a}$ \\
\hline 0.9 & $11.99 \pm 0.19 \mathrm{e}$ & $12.03 \pm 0.54 \mathrm{~d}$ & $12.87 \pm 0.57 \mathrm{~cd}$ & $9.92 \pm 0.31 \mathrm{~b}$ \\
\hline 1.3 & $29.10 \pm 0.88 \mathrm{a}$ & $16.37 \pm 0.24 \mathrm{a}$ & $19.96 \pm 0.33 \mathrm{a}$ & $14.29 \pm 0.37 \mathrm{a}$ \\
\hline 1.8 & $16.49 \pm 0.39 c$ & $13.99_{ \pm 0.19 b c}$ & $14.15 \pm 0.57 c$ & $9.54 \pm 0.27 b$ \\
\hline 2.2 & $13.59 \pm 0.11 \mathrm{~d}$ & $12.74 \pm 0.35 \mathrm{~cd}$ & $11.99 \pm 0.33 \mathrm{de}$ & $9.98 \pm 0.28 b$ \\
\hline
\end{tabular}




\section{CONCLUSION}

This three-step (induction, maturation, and germination) protocol takes only 4-5 months to obtain plantlets from Anthurium crossed lines,via indirect somatic embryogenesis, using Half-strength modified MS medium supplemented with 2,4-D and6-BAP. SEM studies revealed the characteristic development of indirect SEs from leaf to complete plantlets. The embryo-generated plants successfully flowered in the field. The promising protocol developed here for regeneration of crossed Anthurium through indirect somatic embryogenesis may be used in future experiments aiming at genetic transformation and large scale propagation of true to type of plants of Anthurium.

\section{ACKNOWLEDGEMENTS}

This research was supported by Centre for Post-Graduation Studies (CPGS), Jain University and SEM. Studies were performed under the guidance of Dr. Duleep Kumar Samuel, Principal Scientist, Division of Pathology, ICARIndian Institute of Horticultural Research, Bengaluru which are gratefully acknowledged.

\section{REFERENCES}

Abdul Moneim A Al-Shawaf, Saad Al-Abdan, Abdul Hadi AlAbbad, Abdallah Ben Abdallah and J R Faleiro, 2012. Validating Area-wide Management of Rhynchophorus ferrugineus (Coleoptera: Curculionidae) in Date Plantations of Al-Hassa, Saudi Arabia. Indian Journal of Plant Protection., 40(4 ): 255-259

AdelheldR.,Kuchnle, Fure-Chyi and S. Nellie,1992. Somatic embryogenesis and plant regeneration in Anthurium andraeanum hybrids. Plant Cell Report., 11: 438-442.

Atak, Ç.; Çelik, Ö, 2009. Micropropagation of Anthurium andraeanum from leaf explants. Pakistan Journal of Botany., 41(3): 1155-1161.

Bakhsi-Khaniki, G., Ghasemi, M., Bairamizadeh, E., 2011. Study of micropropagation of Anthurium using tissue culture. New Cell Mol. Biotechnol. J. 1 (4): 79-87

Bejoy, M., V.R. Sumitha and N.P. Anish, 2008. Foliar regeneration in Anthurium andraeanum. Hort. Agnihotri. Biotech., 7: 134-138.

Beyramizade E., P. Azadi andM. Mii, 2008. Optimization of factors affecting organogenesis and somatic embryogenesis of Anthurium andraeanum Lind. 'Tera'. Propaga Ornamental Plants., 8:198-203.

Bhattacharya, C., A. Dam, J. Karmakar and T. K. Bandyopadhyay, 2015. Efficient organogenesis from the induced meristemoid of Anthurium andraeanum Linden cv. Tinora. Plant Science Today., 2(2): 82-86.

Bhattacharya, C., A. Dam, J. Karmakar and T. K. Bandyopadhyay,2016. Direct somatic embryogenesis and genetic homoge- neity assessment of regenerated plants of Anthurium andraeanum Linden cv. Fantasia. In vitro Cell. Dev. Biol.-Plant., 52:512-519.

Cardoso, J.C., Habermann, G, 2014. Adventitious shoot induction from leaf segmentsin Anthurium andreanum is affected by age of explant, leaf orientation and plant growth regulator. Hortic. Environ. Biotechnol. 55 (1): 56-62.

Chen, J., McConnell,D.B.Henny, R.J. and K.C Everitt, 2003. Cultural guidelines for commercial production of interior space Anthurium. University of Florida, IFAS extension, EHN956.

Chen, C., X. Hou, H. Zhang, G. Wang and L. Tian, 2011.Induction of Anthurium andraeanum "Arizona" tetraploid by colchicines. In vitro. Euphytica., 181: 137-145.

Dufour L., and V. Guérin,2003. Growth, developmental features and flower production of Anthurium anthurium Lind. In tropical condition. Scientia Horticulturae., 98: 25-35.

Farsi, M., Taghavizadeh, Y. M., \&t Qasemiomran, V, 2012. Micropropagation of Anthurium andreanum cv. Terra. African Journal of Biotechnology., 11(68), 13162-13166.

Geier T., 1986. Factors affecting plant regeneration from leaf segments of Anthurium scherzerianum Schott (Araceae) cultured in vitro. Plant cell, Tissue and organ Culture., 6;115125

Geier T., 1988. Ploidy variation in callus and regenerated plants of Anthurium scherzerianum Schott.ActaHort., 226: 293-298.

Geier T., 1990. In: Ammirato PV, Evans DA, Sharp WR, Bajaj YPS (eds), Handbook of plant cell culture. McGraw-Hill., New York 5: 228-252.

Hamidah, M., A.G.A. Karim and P. Debergh. 1997. Somatic embryogenesis and plant regeneration in Anthurium scherzerianum. Plant Cell, Tissue, Organ Culture, 48: 189-193.

Islam, S.A., M.M.R. Dewan, M.H.R. Mukul, M.A. Hossain and F. Khatun, 2010, In vitro regeneration of Anthurium andreanum cv. Nitta. Bangladesh J. Agril., 35: 217-226.

Kuehnle A.R. and N. Sugii, 1991. Callus induction and plantlet regeneration in tissue cultures of Hawaiian Anthuriums. Hort Sci., 26:919-921.

Kuehnle A.R., F. C. Chen and N. Sugii , (1992). Somatic embryogenesis and plant regeneration in Anthurium andraeanum hybrids. Plant Cell Rep., 11:438-442.

Kunisaki J.T., (1980). In vitro propagation of Anthurium andraeanum Lind. Hort Sci., 15:508-509.

Liendo M., and N. Mogollon, (2009) Multiplicacion clonal In vitro delanturio (Anthurium andreanum Lind. cv. Nicoya). Bioagro., 21:179-182.

Matsumoto T.K., D.T. Webband A.R. Kuehnle, (1996). Histology and origin of somatic embryos derived from Anthurium andraeanum Linden exAndré Lamina. J Am Soc Hortic Sci., 121:404-407.

Matsumoto T.K. and A.R. Kuehnle, (1997). Micropropagation of Anthurium. In: Bajaj YPS (ed) High tech and micropropagation VI. Biotechnology in agriculture and forestry. Springer Verlag, Berlin Heidelberg., 14-29. 
Matsumoto, T. K., Kuehnle, A. R., and Webb, D. T., 1998. Zygotic embryogenesis in Anthurium (araceae). American Journal of Botany., 85(11), 1560-1568.

Martin K.P., D. Joseph, J. Madassey and V.J. Philip, 2003. Direct shoot regeneration from lamina explants of two commercial cut flower cultivars of Anthurium andreanum Hort. In vitro Cell Dev Bio Plant., 39:500-504.

Marcos V. M., P. Fabrina, B. M. Ana Claudia Ferreira da Cruz, 2014. Somatic embryogenesis in anthurium (Anthurium andraeanum cv. Eidibel) as affected by different explants. Acta Scientiarum. Agronomy.Maringá., 36(10):87-98.

Merkle S.A., W.A. Parrot and E.G. Williams, (1990) Applications of somatic embryogenesis and embryo cloning. In: Bhojwani SS(ed) Developments in Crop Science 19. Plant Tissue Culture: Applications and Limitations Elsevier. AmsterdamOxford-Tokyo., 67-101.

Nhut, D. T., D. Nguyen, N. N. H. Vy, C.D. Khue, D. V. Khiem and D. N. Vinh, (2006). Impact of Anthurium spp. genotype on callus induction derived from leaf explants, and shoot and root regeneration capacity from callus. Journal of Applied Horticulture., 8(2): 135-137.

Paola A., Murillo-Gómez, N. Esther, C. Ricardo, A. Lucia and U. Aura, 2014, Micropropagation of the native species Anthurium antioquiense for conservation purposes. Agronomía Colombiana., 32(3): 334-340.

Pence, V.C., (2011). Evaluating costs of the In vitro propagation and preservation of endangered plants. In vitro Cell. Dev. Biol Plant, 47:176-187.

Pierik R.L.M., H.H.M. Steegmans and J.A.J. Van Der Meys, 1974. Plantlet formation in callus tissue of Anthurium andraeanum Lind. Sci Hortic, 2:193-198
Pinheiro MVM, Martins FB, Cruz ACFD, de Carvalho ACPPD, Oliveira EJD, Otoni, WC, (2013). Maturation of Anthurium andraeanum cv. Eidibel somatic embryos from nodal segments. In Vitro Cell. Dev. Biol.-Plant., 49:304-312

Pinheiro MVM, Martins FB, Cruz ACFD, de Carvalho ACPPD, Oliveira EJD, Otoni, WC, (2014). Somatic embryogenesis in anthurium (Anthurium andraeanum cv. Eidibel) as affected by different explants. Acta Sci. Agron., 36(1):87-98

R. Thokchom and S. Maitra, (2017). Micropopagation of Anthurium andreanum cv. Jewel from leaf explants. Journal of Crop and Weed, 13(1): 23-27

Rout G.R., A. Mohapatra and S. Mohan Jain, (2006). Tissue culture of ornamental pot plant: A critical review on present scenario and future prospects. Biotechnol. Adv., 24: 531-560.

Sinta, M. M., Riyadi, I., \&t Sumaryono, (2011). Effect of different culture vessel closures on the growth of oil palm (Elaeis guineensis Jacq.) plantlets. Menara Perkebunan., 79(1): 15-22.

Teixeira D.A., J.A. Silva, J. Dobránszkib , B. Winarto , S. Zeng, (2015). Anthurium In vitro: a review. Sci Hortic., 186:266-298.

Thaneshwari H and C Aswath, (2018). Effect of plant growth regulators and sucrose concentration on callus induction and shoot differentiation from ovary culture of marigold (Tagetes $s p p$ ). International Journal of Chemical Studies, 6(1): 618-623

Viegas, J., M.T.R. Rocha, I. Ferreira-Moura, D.L. Rosa, J.A. Souza, M.G.S. Correa and J.A.T. Silva, (2007) Anthurium andraeanum (Linden ex Andre) culture: In vitro and ex vitro. Floric. Ornam. Biotech.,1: 61-65.

Yu, Y.X., Liu, L., Liu, J.X., Wang, J.,( 2009). Plant regeneration by callus-mediated protocorm-like body induction of Anthurium andraeanum. Hortic. Agric. Sci.China., 8 (5):572-577. 